811.163.41'367.625

https://doi.org/10.18485/sj.2018.23.1.12

\author{
ЈАСМИНА Д. МОСКОВЉЕВИЋ ПОПОВИЪ \\ Оригинални научни рад \\ Универзитет у Београду \\ Примљен: 04. 01. 2018. \\ Филолошки факултет \\ Прихваћен: 29. 01. 2018.

\section{О БЕНЕФАКТИВНИМ КОНСТРУКЦИЈАМА С ГЛАГОЛИМА ТИПА „ДАРОВАТИ”**}

Рад је посвећен анализи конструкција са бенефактивним значењем у којима се јављају глаголи типа „даровати”. Специфичност конструкција које се формирају са глаголима овог типа огледа се у могућности њихове реализације у два различита структурна лика: у конструкцији $\mathrm{V}+\mathrm{NP}_{1 \text { acc }}+\mathrm{NP}_{2 \text { ins }}$ која алтернира са конструкцијом $\mathrm{V}+\mathrm{NP}_{1 \text { dat }}+\mathrm{NP}_{2 a c c}$. У првом, уводном делу рада представљене су неке опште карактеристике конструкција са бенефактивним значењем, као и општа својства конструкција са синтаксичким алтернацијама. У другом, централном делу рада су на основу прикупљене грађе идентификовани глаголи који се сврставају у класу „даровати” и анализирана су лексичка и структурна обележја бенефактивних конструкција у оквиру којих се они реализују. У трећем, завршном делу рада указано је на општа, заједничка својства која одликују овај тип синтаксичких конструкција, као и на однос који се успоставља између њих и значењски и валентно сродних конструкција.

Кључне речи: глаголска класа „даровати”, синтаксичке алтернације; бенефактор, бенефицијент; лексичко-валентни континуум; савремени српски језик

"jasmina.moskovljevic@fil.bg.ac.rs

** Овај рад настао је у оквиру пројекта Стандардни српски језик: синтаксичка, семантичка и прагматичка истражсивања (178004), који финансира Министарство просвете и науке Републике Србије. На 47. Међународном научном састанку слависта у Вукове дане, Београд, 14-18. IX 2017. изложен је под насловом Дескриптивни речници као извор података за успостављање лексичко-синтаксичких класа глагола један мањи део грађе који се (мада из сасвим другог угла и са сасвим другачијим циљем) анализира и у овом раду. Захваљујем се свим учесницима секције на изузетно корисној и подстицајној дискусији која ме је и навела да се бенефактивним конструкцијама позабавим и из другог угла. 


\section{1. УВОД}

Овај рад настаје са двојаким циљем: 1) да се на основу информација и грађе прикупљене из различитих извора испита величина и састав класе глагола уз коју је могућа инверзија/ротација допуна у једном типу конструкција са бенефактивним значењем (Иван је даровао Ани књигу : Иван је даровао Ану кьигом); 2) да се по извршеној анализи издвоје заједничка структурна обележја овог типа конструкција и одреди њихов однос према значењски и валентно сродним конструкцијама (Марко је Ану частио тортом и Марко је Ани купио торту).

Конструкције са бенефактивним значењем у савременом српском језику обухватају више структурно разнородних реченичних типова, у којима се јављају глаголи са различитим, међусобно несродним значењем: Позајмио ми је књигу.// Направила је торту за брата.// Наградила га је осмехом// Дао јој је пуно новиа.// Свако вече пева успаванку свом детету.// Сазидао је библиотеку за своје суграђане.// Судбина му је подарила много тога, али не и памет.// Onрао је судове уместо сестре.// Омогућиће му убрзано напредовање/да убрзано напредује .... - овде су наведени само неки од њих. ${ }^{1}$ Заједничко им је да се у свим у функцији предиката јављају тровалентни дитранзитивни глаголи у чијој су аргументској структури присутни: 1. аргумент који је носилац семантичке улоге бенефактор, који је агентивног типа, или се перципира као такав (нпр. „судбина”, „провиђење” и сл.), 2. аргумент који је носилац семантичке улоге бенефииијент, или „наумљени реципијент” (Кристал 1985: 32) у чију се корист, или за чије се добро догађај исказан реченицом и одиграва, и 3. аргумент који је носилац семантичке улоге тема и који означава ентитет (конкретне или апстрактне природе) који је предмет трансфера између бенефактора и бенефицијента (Китила и Зуњига 2010). Семантичкој улози бенефицијент блиска је семантичка улога реципијент, али између ове две улоге постоји и значајна разлика - улога реципијента, између осталог, не подразумева да ће се догађај исказан реченицом нужно вршити у корист реципијента (в. примере наведене у напомени 1). Исто тако, радња се може вршити и извршити у нечију корист, а да при томе не дође до „преузимања”, тј. бенефицијент не мора нужно да буде и реципијент (нпр: Поставила је сто за госте или Наместила је мајци кревет). Као и бенефактор, и бенефицијент је најчешће носилац обележја [+ animans; + волунтативност] - семантичка релација бенефактивности управо и подразумева да ће бенефицијент бити способан да прихвати и искористи

\footnotetext{
${ }^{1}$ Треба, међутим, имати у виду да се неки од ових глагола могу употребити и у конструкцијама са потпуно супротним (малефактивним) значењем. Уп.: Дао јој је пуно новца : Дао јој је отказ, или Пренео јој је пакет : Пренео јој је мале богиње.
} 
резултате догађаја (трансфера) који се врши у његову корист (Блејк 1994: 70, Леман et al. 2000: 68). ${ }^{2}$

Када је о другом својству анализираних конструкција реч, терминолошким изразом ротација/алтернаиија/инверзија/пермутаиија допуна означавају се могуће алтернације, односно прекомпозиције у врсти, синтаксичким функцијама и морфосинтаксичком облику глаголских аргумената. Овакве формалне прекомпозиције при којима број семантичких аргумената глагола остаје исти, али се мењају односи које успостављају према предикату, што доводи и до промена у свеукупној структури реченице, допуштене су само уз чланове појединих глаголских поткатегорија. Да ли одређени глагол припада једној од тих поткатегорија, утврђује се применом дистрибуционог критеријума, односно применом теста супституције (Московљевић 2000:293, Московљевић Поповић 2007:70). Овај тип синтаксичких алтернација, који почива на могућности реализације глаголских аргумената у више различитих структурних конфигурација, уочен је и описан у многим, како индоевропским, тако и језицима који припадају другим језичким породицама (Маљчуков et al. 2010).

У савременом српском језику издвајају се два основна типа конструкција са бенефактивним значењем у којима је могућа пермутација допуна: 1) конструкција $\mathrm{V}+\mathrm{NP}_{1 \text { dat }}+\mathrm{NP}_{2 \text { acc }}$ која алтернира с конструкцијом $\mathrm{V}+\mathrm{NP}_{\text {lacc }}+\mathrm{NP}_{\text {2ins }}$ (Иван је даровао Ани књигу: Иван је даровао Ану књигом); 2) конструкција $\mathrm{V}+\mathrm{NP}_{1 \text { dat }}+\mathrm{NP}_{2 a c c}$ која алтернира с конструкцијом $\mathrm{V}+\mathrm{NP}_{1 a c c}+\mathrm{PPK} z a+\mathrm{NP}_{2 a c c}$ (Кројач је Ани сашио хаљину: Кројач је сашио хаљину за Ану). ${ }^{3},{ }^{4}$ Предмет анализе у овом раду су конструкције првог типа. Оне се, иначе, у граматикама и студијама са јужнословенских простора или уопште не помињу, или се помињу само спорадично. Тако М. Ивић, говорећи о употреби именичких синтагми у инструменталу уз (само) два глагола из ове групе (нудити и служити), истиче да „они ни на који начин и ниуколико не носе спроводничку функцију...”, већ да ,претстављају управо само обавезни објекат подразумеване акције коју носи у себи претстава значења одређене глаголске радње (Ивић 1954: 23). Ивић не говори о могућности алтернације допуна уз наведене глаголе, али у наставку текста износи занимљив дијахронијски податак да је „овај ... тип инструментала познат још из језика Веда ... и био је некада раширен у индоевропским језицима" (ibid.), што свакако објашњава данашњу релативно велику заступљеност

${ }^{2}$ Носилац семантичке улоге бенефицијент може, наравно, бити и заједничка или властита именица која означава организацију, институцију, компанију и сл. (чији су чланови људи).

${ }^{3}$ Други тип алтернације уочио је М. Ковачевић (1992: 127), који примећује: „Изван наведеног круга лексема што долазе у централној позицији синтагме, понекад се у акузативу с предлогом за као синоним јавља датив намјене и адресата, као нпр.: Купио сам поклон за мајку. - Купио сам поклон мајц̧и."

${ }^{4}$ Оба типа алтернација би у литератури на енглеском језику била означена термином dative alternation. В., нпр., Левин 2013. 
конструкција овог типа у различитим језицима. Стевановић (1979: 443) наводи два примера са глаголом послужити (Крчмар ме послужи тврдим, лошим вином (Шимуновић) и Послужене су слатким, водом и кафом (Андрић)), не помиње могућност пермутације допуна, а инструментал у овим примерима одређује као средство, грађу, материју „која служи да се њом дотична радња врши". Московљевић Поповић, говорећи о различитим могућим типовима синтаксичких алтернација у српском језику, помиње и ротацију допуна уз глаголе типа „даровати” и наводи да је она могућа и уз глаголе нудити, понудити, служити и послужсти, ${ }^{5}$ али не нуди никакву даљу анализу овог типа конструкција (ibid.: 75-76). Разматрајући моделе четворочланих реченица с тровалентним предикатом, В. Ружић наводи да се међу глаголе „који отварају место не само субјекатском аргументу него истовремено и двема, најчешће објекатским допунама” сврставају и „глаголи нудити, частити, даровати и сл., који се такође повезују са три аргументска израза од којих трећи означава предмет „понуде”, што се јасно показује у еквивалентној реченици: Мара га је понудила пићем ↔ Мара му је понудила пиће. Глагол частити има, поред акузативске, само инструменталску рекцију, тако да се остварује као и глагол понудити по горе наведеном синтаксичком обрасцу: Частим све присутне колачима (Ружић 2005: 525-526). Ружић на овај начин идентификује неке од чланова глаголске групе „даровати” и указује на могућност њихове реализације у алтернативним синтаксичким конфигурацијама, али их даље не истражује, нити прецизно разграничава од групе глагола чије се допуне реализују само у оквиру модела $\mathrm{V}+\mathrm{NP}_{1 a c c}+\mathrm{NP}_{2 i n s}$, односно од групе глагола уз коју алтернација допуна није могућа (којој припада и једини члан ове групе кога наводи, глагол частити). Досад најдетаљнију анализу синтаксичког понашања глагола типа „даровати” понудила је Ирена Зовко Динковић (2007). Међутим, неки од резултата до којих је она дошла, значајно се разликују од резултата до којих се дошло у овом раду (в. ниже).

\section{2. ЛЕКСИЧКА И СТРУКТУРНА ОБЕЛЕЖЈА БЕНЕФАКТИВНИХ КОНСТРУКЦИЈА СА ГЛАГОЛИМА ТИПА „ДАРОВАТИ”}

Највећи део грађе анализиране у овом раду ексцерпиран је из шестотомног речника Матице српске која је у неким случајевима, кад је то било потребно, допуњена и грађом из различитих извора доступних на интернету

${ }^{5}$ Уз наведене, Московљевић Поповић погрешно сврастава и глагол исплатити. Иако се уз овај глагол допуне реализују у истом морфосинтаксичком облику као и уз глаголе из групе ,даровати”, не постоји и одговарајући паралелизам у значењу кореспондентних конструкција, па се глагол исплатити (као, нпр., ни глаголи обезбедити, платити) не могу сврастати у исту класу са глаголима типа „даровати”. Уп.: Он јој је исплатио новаи : Он ју је исплатио новцем vs. Он јој је даровао скупоцену огрлииу : Он ју је даровао скупоценом огрлицом. 
како би се обезбедио што бољи увид у својства анализираних конструкција. У грађи је идентификовано укупно 15 глагола уз које је могућа алтернација допуна у конструкцијама са бенефактивним значењем: даровати, даривати, дарити, надарити, подарити, подаровати; нудити, понудити, нуткати, нуђати, занудити; служити, послужити, послуживати и донирати. Од тога су четири основна (даровати, нудити, служити и донирати), док су преосталих једанаест глаголи који су из основних изведени различитим творбеним процесима.

2.1. Глагол даровати и деривационо сродни глаголи даривати, дарити, надарити, подарити и подаровати реализују се у обе структурне конфигурације, мада са различитом учесталошћу, како када је реч о фреквенци употребе појединих глагола, тако и када се разматра њихова заступљеност у једном од два могућа типа конструкција:

\section{ДАРОВАТИ}

a) у конструкцији $\mathrm{V}+\mathrm{NP}_{1 \text { acc }}+\mathrm{NP}_{2 \text { ins }}$ :

Млада у овим селима сватове дарује чарапама и комуљама. (www.blic.rs)//... уколико је било другог повода да наврате па виде дјете, они који су били у могућности даровали су га новием... (www.ntv.ba)// Мушки су то полијевање плаћали - даровали су младу новием. (priceizbosne.blogspot.com)// Учитељи нас даруjу својим стрпљењем и знањем. (os-kustosija-zg.skole.hr)// Она не описује ғихове јуначке особине, већ телесну лепоту и ношюу, и посебно истиче чиме су је даровали. (www.blic.rs)// Брак је био дарован многом децом. (MC3)// ... јер су ирквени тутори приликом богослужења подносили свечарима иконе да их иеливају и даруjy новием. (https://books.google.rs)

б) у конструкцији $\mathrm{V}+\mathrm{NP}_{1 d a t}+\mathrm{NP}_{\text {2acc }}$ :

Дарова сваком брату убрус и чарапе. (MC1)// Дарова му кошуљу од злата, заклопи му руке око врата. (МС2)// Калупаи сапуна [ми је] тетка даровала. (МС2)// Даровао му ㄹ многа села, иркве и метохе. (МС3)// Даровао ми ⿺ㅡ ... неколико серија старих енглеских и колонијалних марака. (МС5)// Даровао је ... у добротворне сврхе тридесет хиљада... (МС4)

\section{ДАРИВАТИ}

a) у конструкцији $\mathrm{V}+\mathrm{NP}_{\text {lacc }}+\mathrm{NP}_{\text {2ins }}$ :

Тер их [ага] турскијем даривао даром: ... коме колаи, коме ли конопаи. (MC1)// Даривао их [дјеиу] острижинама од свакојаких крпа. (МС4)// Дарива [наконче] кошуљьииом, па га предаде матери. (МС1)// Ујак свећеник. .. ме је једном .. . крижаром даривао. (MC3)// Е да ли јој засенише очи богати поклони којима је дарива [он]? (MC2)// Чудне ми кавалиритине, дивне ли племенитости, даривати некога туђом робом. (МС2)// Николић је ... рекао да га је судбина даривала изузетном чамћу да... (www.politika.rs)// Паде му на памет да су његови пређи од памтивијека помагали и даривали ту исту иркву. (МС4)

б) у конструкцији $\mathrm{V}+\mathrm{NP}_{1 d a t}+\mathrm{NP}_{2 a c c}$ :

Дарива му од вела кошуљу. (MC1)// Староме је Матку оставио докуменат на суду којим дарива Мади двораи. (МС1)// Загорка . . видовитост посинку дарива. (МС2)// Му- 
зиканти су даривали пролазницима своју крхку и прилично меланколичну, сипљиву ноту. (МС3)// Ма још Драго недовољан бива, ито му нитко диљке не дарива. (МС3)// Пошто му угодно послуже у овом веку, дарива им вечна добра. (old.fil.bg.ac.rs)

\section{ДАРИТИ}

a) у конструкцији $\mathrm{V}+\mathrm{NP}_{1 \text { acc }}+\mathrm{NP}_{2 \text { ins }}$ :

Земља га [храст] са трулежом дари. (MC1)

б) у конструкцији $\mathrm{V}+\mathrm{NP}_{1 \text { dat }}+\mathrm{NP}_{2 a c c}$ :

А дари му на трапези паче сувог злата. (ПС; www.rastko.rs )

\section{НАДАРИТИ}

\section{a) у конструкцији $\mathrm{V}+\mathrm{NP}_{1 \text { acc }}+\mathrm{NP}_{2 i n s}$ :}

За заслуге у градњи аустријских жељезница надарио га је наш ияар и краљ 1860. године аустријским насљедним племством (то му је било најјефтиније)... (www. zeljeznice.net)// Зашто се фашисти праве глупи кад их је природа несебично надарила глупошћу? (www.jutarnji.hr)//...а на крају их je све надарила некаквим сластицама ... (www. spiritofbosnia.org)// Но, ако их је Мајка Природа надарила посебно бритким и лукавим умом ... постаје потпуно неважно што их је начинила тако маленима. (http://www. bibliovcica.com)// ... надарила ју је она силним благом и драгоијеним даровима. (https:// archive.org)// На одласку Бука ме увијек надари неком књигом (својом или туђом)... (www. matica.hr)// Многобројна публика је надарила младе глумие и музичаре бурним аплаузом. (www.bildungsserver.com)// Обје базилике њезин син Константин богато надари и даде их раскошно уресити. (www.zg-nadbiskupija.hr)

б) у конструкцији $\mathrm{V}+\mathrm{NP}_{1 \text { dat }}+\mathrm{NP}_{2 a c c}$ :

Мајка природа нам то надарила, рецимо судбина итд. (www.haoss.org)// ... нека искористи све предности које јој је природа надарила...// (www.forum.hr)// ...nрирода ти је надарила и спољьу и унутрашњу лепоту! (https://www.instagram.com)// Уколико вам природа није надарила идеалан метаболизам и атлетску фигуру, за постизање оптималне телесне тежине се морате потрудити сами. (www.b92.net)// Haдари срећу сестрама, мени и намој мами. (www.most.ba)

\section{ПОДАРИТИ}

\section{a) у конструкцији $\mathrm{V}+\mathrm{NP}_{1 \text { acc }}+\mathrm{NP}_{2 \text { ins }}$ :}

Трипут сам те подарио својим милосрђем. (МС4)// Бритем пьувачку којом ми је ... лиие подарио. (MC4)// Природа нас је подарила невероватном способношћу за камуфлажу. (www.fokuzz.com)// Марс у вашем знаку подариће вас енергијом и мотивачијом... (bezpitanja.rs)//...али зато нас је подарио упорношћу, мудрошћу, сналажљивошћу... (www. roditeljportal.com)// ... судбина ме подарила великом чашћу да могу ... (www.index.hr)

\section{б) у конструкцији $\mathrm{V}+\mathrm{NP}_{1 \text { dat }}+\mathrm{NP}_{2 a c c}$ :}

Професор му [је] подарио двије сребрне двосексерке. (MC1)// Подари суние једрини гроздова, бобуљи смреке. (МС1)// Када бих имала здравља, подарила бих му га у иелости... (www.vreme.com)// Моја мајка мом оиу није подарила сина. Али му је подарила мене. 
(www.kriticnamasa.com)// Задржите ме у сећању, будући да ми судбина није подарила довољно живота да... (www.rts.rs)

\section{ПОДАРОВАТИ}

a) у конструкцији $\mathrm{V}+\mathrm{NP}_{\text {1acc }}+\mathrm{NP}_{2 \text { ins }}$ и б) у конструкцији $\mathrm{V}+\mathrm{NP}_{1 \text { dat }}+\mathrm{NP}_{2 \text { acc }}$ : Боже... подаруі ме добрим здрављем ... подаруі ми свако добро. (MC4)

У прикупљеној и анализираној грађи чести су примери са глаголима $\partial a-$ ровати, даривати, надарити и подарити како у старијем, тако и у савременом језику, док се глаголи дарити и подаровати јављају само по једном у сваком структурном обрасцу и сви примери са овим глаголима потичу из старијег језика (при томе се глагол подаровати реализује у оба структурна обрасца у једној истој реченици). Иако је носилац улоге бенефицијент по правилу именичка фраза са обележјем [+ animans], забележени су и примери где то није случај: у последњим наведеним примерима уз глаголе даровати, даривати и надарити бенефицијенти су „иконе”, „црква” и „обе базилике”.

За глаголе надарити и подарити карактеристично је да су заступљенији у конструкцији $\mathrm{V}+\mathrm{NP}_{1 a c c}+\mathrm{NP}_{2 i n s .}$, као и да се уз њих као носилац семантичке улоге бенефактора често јавља и именичка фраза са значењем „више силе” - природа, судбина и сл. Занимљиво је и да се значењски и творбено сродан глагол обдарити уопште не може појавити у алтернативној конструкцији $\mathrm{V}+$ $\mathrm{NP}_{1 \mathrm{dat}}+\mathrm{NP}_{2 \mathrm{acc}}$ (уп. Природа га је обдарила благом и веселом нарави: "Природа му је обдарила благу и веселу нарав). Више него било шта друго ово указује на примарно лексичку заснованост синтаксичких алтернација овог типа.

2.2 Основни глагол нудити и из њега изведени глаголи понудити, нуткати, нуђати и занудити сачињавају другу подгрупу глагола који се реализују у алтернативним структурним конфигурацијама $\mathrm{V}+\mathrm{NP}_{1 \text { acc }}+\mathrm{NP}_{2 \text { ins }}$ или $\mathrm{V}+\mathrm{NP}_{1 \text { dat }}+\mathrm{NP}_{\text {2acc }}$ :

$$
\text { нУдити }
$$

a) у конструкцији $\mathrm{V}+\mathrm{NP}_{1 \text { acc }}+\mathrm{NP}_{2 \text { ins }}$ :

Нуди своје пријатеље мочом. (МС3)// А нови архимандрит ... нуди госте ђаконијама, старајући се збиљски да сваки оде ... задовољан.... (МС4)// Јелом и пићем од сриа нудиш. (МС3)// Жене су се у гужви препознавале ... нудиле се ракијом и лубенииама. (МС3)// Нудио га је вечером и био је упоран. (www.blic.rs)// Летјет ћеш, нудиће те дрогом. (titles.box.sk)// Ортаии ће те зезати што нећеш да пијеш, нудиће те иигаретама... (www. dominomagazin.com)// ...и нудио нас леком за све болести.//... ал'онда ме не би ни нудили тим радним местом. (https://vukajlija.com)// Девето, никада нисам од стране Бошњака био нућен новием да одрађујем патриотске, уставне активности... (www.sokovi.net)//... да је дуго кметовао, да је нућен разним почастима, али их није хтео примати (www. poreklo.rs)// Зар ме нудищ оглушиима (= непослухом), јогунаста врачаро? (MC3)// Симка га куне и прекорева за пажюу и нежност којом га 르 толико година нудила. (MC4) 
б) у конструкцији $\mathrm{V}+\mathrm{NP}_{1 \text { dat }}+\mathrm{NP}_{2 a c c}$ :

Нудише Наполеону увјете мира које може нудити само ... надвладани добитнику. (МС1)// Лијечник [га је] озбиљно . . . мотрио и нудио му капьице. (МС2)// Моја им лакомрзна нарав нуди чисту љубав. (МС3)// Ту ми одавна [нудище] напутице и напојнице ... (МС3)// Нико ми ниита није нудио (www.novosti.rs)// Преко њега [сте] нудили нагодбу. (МС3)

\section{ПОНУдити}

\section{a) у конструкцији $\mathrm{V}+\mathrm{NP}_{1 \text { acc }}+\mathrm{NP}_{2 \text { ins }}$ :}

Лугарева жена могла их је понудити само кукурузним жганцима с киселим врхњем. (MC1) // Дозовне жену да их понуди пићем. (MC1)// Кад га Јованка понуди кафом, чича забрсти: ... (МС2)// Она га је најпре позвала да седне и понудила га амброзијом и нектаром. (alas.matf.bg.ac.rs)// Могло [се] десити да је какав кум понуди полчетвртаком. (МС4)// Необично [му је] ласкало кад су га понудили кандидатуром за саборског заступника. (MC4)

б) у конструкцији $\mathrm{V}+\mathrm{NP}_{1 \text { dat }}+\mathrm{NP}_{2 a c c}$ :

Дај да Турчима ... свјета понудимо да ... не маљу заграбљиве главе... (МС2)// Понудила му једну-двије чашице ... бољега пића, пошто се нагриао патворених ракија. (МС3)// Немајући достојна кавалира, понуди ... сама Борису мазурку. (МС4)// Он би пожурио за њом хотећи да јој понуди помоћ. (МС4)// Сестра му понуди лимунаду. (MC4)// Позвао сам вас ... да вам понудим један портфељ у кабинету. (MC4)// Понудит ћy Плавчићу двоструку своту да ми препрода кућу. (MC4)// Понудим своја три рукописа на откуп. (MC4)

\section{НУТКАТИ}

\section{a) у конструкцији $\mathrm{V}+\mathrm{NP}_{1 \text { acc }}+\mathrm{NP}_{2 \text { ins }}$ :}

Нутка га воћем или закуском. (МС2)// Нуткајући се јелом и пићем, фратар и странаи су с времена на време погледали један другог. (МС3)// Она је била строга, није га нуткала слаткишима. (www.manastir-lepavina.org)// Ана је држала његову главу у крилу и нуткала га лимунадом, преслатком. (https://eteia.home.xs4all.nl)// ...а када је недавно био у нашој кући мама је само мене нуткала храном (www.novine.ca)

\section{б) у конструкцији $\mathrm{V}+\mathrm{NP}_{1 \text { dat }}+\mathrm{NP}_{2 a c c}$ :}

С времена на време сам му нуткала „Аптамил”. (www.roditeljportal.com)// „Ajде попи једну, ваља се", нуткала му ракију. (www.ukat.org.rs)// Јутрос сам јој свашта нешто нуткала и на крају ништа није узела. (www.ringeraja.rs)//...jер цисам нешто посебно нуткала људима каталоге. (www.mojekrpice.rs) // Партија са највише коаличионе потенције редовно се(бе) нутка(ла) двојичи повећих и посве различитих партнера... (www.danas.rs)

\section{НУЂАТИ}

a) у конструкцији $\mathrm{V}+\mathrm{NP}_{1 \text { acc }}+\mathrm{NP}_{2 \text { ins }}$ : 
б) у конструкцији $\mathrm{V}+\mathrm{NP}_{1 \text { dat }}+\mathrm{NP}_{2 a c c}$ :

Поновно му [је] нућала крух. (МС3)// У кући га пазили као свога, удобе и повољище

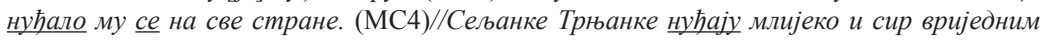
постоларицама. (MC4)

\section{ЗАНУДИТИ}

a) у конструкцији $\mathrm{V}+\mathrm{NP}_{\text {lacc }}+\mathrm{NP}_{\text {2ins }}$ :

И зануди га [дијете] својим млијеком. (МС2)// Зануди га да је [каву] попије. (МС2)

б) у конструкцији $\mathrm{V}+\mathrm{NP}_{1 \text { dat }}+\mathrm{NP}_{2 a c c}$ :

Да им домаћин зануди плату, они би се ... (AJ)

Слично као и са глаголима из прве подгрупе, и овде се од пет глагола два јављају врло ретко (нуђати и занудити) и то само у старијим изворима. Преостала три глагола (нудити, понудити и нуткати) присутна су и у савременом језику у обе структурне конфигурације. Иако Зовко Динковић (2007: 79) тврди ${ }^{6}$ да уз ову групу глагола, када се реализује у конфигурацији $\mathrm{V}+\mathrm{NP}_{1 a c c}$ $+\mathrm{NP}_{\text {2ins }}$, именичка фраза у инструменталу која је носилац семантичке улоге тема мора означавати (искључиво) храну, пиће, или цигарете/дуван, примери из грађе то демантују - у њима бенефактор бенефицијенту нуди: лек, дрогу, пажну, нежност, непослушност, радно место и кандидатуру за саборског заступника, док се у две реченице са пасивном конструкцијом бенефицијенту додатно нуде још и новач и разне почасти (в. наведене примере). Значи, иако у већини примера предмет трансфера јесу храна, пиће и цигарете/дуван, што указује да глаголи ове групе у конфигурацији $\mathrm{V}+\mathrm{NP}_{1 \text { acc }}+\mathrm{NP}_{\text {2ins }}$ постављају строже селекционе рестрикције на избор друге допуне и у извесној мери сужавају опсег значењских обележја која она мора поседовати, то ипак не значи да су те селекционе рестрикције постављене тако искључиво као што се то у литератури сугерише. Као додатни аргумент у прилог овој тврдњи могу се навести и примери реченица у којима функцију друге допуне уз ове глаголе не врши $\mathrm{NP}_{2 i n s}$, већ клауза, што опет указује да њен избор није ограничен само на именичке фразе које означавају храну, пиће и дуван:

Чича Митар понуди ... домаћине да поседају на храстову клупу. (МС2)// Понудили га да буде апсаниија у Солуну. (МС4)// Када им је друго ... предузеће понудило да ... одржава ту исту линију, монополисти су ... рекли не! (МС3)// Кад сам вам ... пре неколико дана нудио да се предбројите на неке наме кьиге ... ви ме просто одбисте. (МС4)// Турии га најпре нуђаху да се потурчи, а када он то одлучно одби, обесе га 1657. године. (www.voanerges.rs).

${ }^{6}$ Исту тврдњу изнео је и М. Ковачевић у излагању „Интердепенденција пермутабилних форми правог и неправог објекта у синтагмама с глаголом нудити” на 47. МСЦ-у (2017.). 
2.3 И уз тровалентне дитранзитивне глаголе служити, послужити и послуживати могуће је ротирати директни и индиректни објекат уз истовремену измену падежних обележја именичких фраза:

\section{служити}

a) у конструкцији $\mathrm{V}+\mathrm{NP}_{\text {lacc }}+\mathrm{NP}_{2 \text { ins }}$ :

Почеше служити чајем са прженим ... крухом. (МС3)// Чим гости дођу и седну у кућу по старешинству, сродству и пријатељству, служе их кафом и ракијом. (https:// books.google.rs/books)// После поздрава млада узима табак (послужавник) и служи госте ракијом или слатким, а чакалени служе ракијом и кафом. (https://books.google.rs/books)// ... рекла је председница ДСС-а, која је тортом служила госте. (http://www.rts.rs)

\section{б) у конструкцији $\mathrm{V}+\mathrm{NP}_{1 \text { dat }}+\mathrm{NP}_{2 a c c}$ :}

Пода њ [шатор] сједе ладно пити вино, служи муга китна Анђелија. (MC2)// Ceоске девојке у кломпама слуюиле су нам ракове. (МC2)// У прошлости је младенкин отаи служио само ракију зету и његовој родбини... (www.hercegovina.info)//... где нас је, редовно, служсила великим слатким бухтлама и чудесно укусним соком од малина. (https://books. google.rs)// На ходнику момци слюжаху напитком војнике. (https://sr.wikisource.org)

\section{послУжити}

a) у конструкцији $\mathrm{V}+\mathrm{NP}_{\text {lacc }}+\mathrm{NP}_{2 \text { ins }}$ :

Бар са вргом студене водице да те млада невеста послужи. (MC1)//A кад ћеш нас послужсти захарама? (МС2)// Кад их је Цинцарин изнова кавом и ракијом послужсио, они се згледаше значајно. (МС2)// Старамајка их послужи ракијом и топлим ломљеним хлебом. (МС4)// Када су се јелом подмирили, Милош их ㄹ вином послужио. (МС4)// Вилшир је прошао између Доналда и Канге, послужио лоптом Волкота, овај је пребаиио на петераи до Жируа... (www.pravda.rs)// ... а посетиоци ће на отварању бити послужсени куваним вином и ракијом.(rtvpancevo.rs)//... с мноштвом студената волонтера који су скрбили за то да сви судионици буду послужени информачијама или окрјепом... (www. archive-hr-2013.com)// Јесте ли често послужени информачијама о познатим фацама које гостују на нашем мору ...? (www.hrvatskarijec.rs)// ... да Вас послужи правим информацијама о заиста трајном решењу Вашег проблема... (www.infomarket.co.rs)// Момак их одмах послужи кавом и дуваном, а на дати знак као нечујна сенка изгуби се. (ДБ_ЂМ)// ... послужи га, мада нерадо, дуваном из Хериег Босне. (ДЂ_СВ)

\section{б) у конструкцији $\mathrm{V}+\mathrm{NP}_{1 \text { dat }}+\mathrm{NP}_{2 a c c}$ :}

А мрку му каву послужсила, иза каве бистрииу ракију. (МС1)//А најбоља вијетнамска јела послужили су нам у берлинском „Мр Шонгу”... (www.gloria.rs)// Отишли смо у један романтични ресторан, послужили су нам леп десерт ... (glossy.espreso.rs)// Послужсли су нам питу са шлагом. (https://www.vice.com)// Два сата након поласка nослужили су нам вечеру. (www. tripologia.com)// Љубазно су нам на рачун куће послужили лимунћело. (www.putovanja.info)// ... простор који одише љубављу је право мјесто гдје ћете послужити романтичну вечеру. (www.nezavisne.com) 


\section{ПОСЛУЖИВАТИ}

a) у конструкцији $\mathrm{V}+\mathrm{NP}_{\text {lacc }}+\mathrm{NP}_{\text {2ins }}$ :

Примати »визите«, послуживати их кафом... (MC1)//Ребека је држала бебу у рукама и послуживала их чајем.(engleskifudbal.com)// ...када су такмичари оштрили сечива својих коса, публика их је соколила, послужсивала водом и освежсавајућим напицима (www.politika.rs)//...а у више наврата кафом их је послужсивала 3. П., која је живела са Милосавом. (www.novosti.rs)// Док су маме уживале у дружењу, деца су их послуживала кафом, соковима и тортом. (https://sr-rs.facebook.com)// Пићем и храном послуживала нас .е једна средовечна жена... (www.knjizevnicasopis.com)

б) у конструкцији $\mathrm{V}+\mathrm{NP}_{1 \text { dat }}+\mathrm{NP}_{2 a c c}$ :

Док нас је она послуживала чајем, Влад је испратио једног који је управо завриио боравак. (glaszapadnesrbije.rs)// Гостима је често послуживао ухолаже, змије и пите од меса носорога.(https://www.express.hr)// Кухала сам топле напитке и послуживала их факултетском особљу. (https://issuu.com)//...која нам је припремала и послуживала обеде... (www.sidskiportal.net)//... и у њему гостима оближњег кафића-послужсивао каву и кифличе (www.slobodnadalmacija.hr)// ... који ће јој певати песму из „, Мале сирене” док јој буде послужсивао храну. (mondo.rs)// ...док он буде послуживао пиће она прича нешто као ... (www.teen385.com)

Употреба ова три глагола у алтернирајућим бенефактивним конструкцијама у савременом језику чешћа је од употребе глагола из претходне две групе - они се јављају како у књижевним, тако и у различитим другим врстама текстова - у разговорном језику, као и у језику штампе, огласних материјала, блогова и сл., што сведочи о продуктивности овог типа синтаксичке алтернације, не само у старијем, већ и у савременом језику. Ни за ову групу глагола не важи ограничење о коме говори Зовко Динковић (ibid.) да именичка фраза у инструменталу може означавати само храну и пиће - бенефицијенту су у примерима наведеним уз глагол послужити понуђени, односно послужени „лопта”, „дуван” и „информације”.

2.4. На крају, као додатни аргумент којим се поткрепљује тврдња да је тип синтаксичке алтернације у коме конструкција $\mathrm{V}+\mathrm{NP}_{\text {lacc }}+\mathrm{NP}_{2 \text { ins }}$ алтернира са конструкцијом $\mathrm{V}+\mathrm{NP}_{1 d a t}+\mathrm{NP}_{\text {2acc }}$ присутан и продуктиван и у савременом језику, могуће је навести примере са глаголом „донирати”, који је тек у новије време преузет у вокабулар српског језика и не налази се ни у једном од претраживаних речника:

\section{ДОНИРАТИ}

a) у конструкцији $\mathrm{V}+\mathrm{NP}_{\text {lacc }}+\mathrm{NP}_{\text {2ins }}$ :

Олимпијски комитет нас је донирао опремом за медицинска испитивања. (www. rzsport.gov.rs)// Полииија донирала школе опремом за едукаиију о сигурном судјеловању у промету. (https://trend.com.hr)//... донирао је опремом и играчкама новоотворени дјечји вртић у Ловасу. (www.skyscrapercity.com)// Ученици су симболично донирали удругу псећом 
храном и посластицама. (www.os-ntesla-ri.skole.hr)// ... преко којих су ротаријанции опремом и новцем донирали сочијално угрожене... (https://issuu.com/rotary_magazin)

б) у конструкцији $\mathrm{V}+\mathrm{NP}_{1 \text { dat }}+\mathrm{NP}_{2 a c c}$ :

Дванаест привредних субјеката из Лесковца и Власотинца донираће Опитој болници Лесковац око пет милиона динара. (www.tvl.rs)//Легендарни кошаркашки тренер сав приход од свог опроштајног меча ... донираће Дечјој клиници у Тириовој. (http://www. blic.rs)// Запослени у МШ „Живорад Грбић” и синдикат запослених ... донирали су новау Центру за вантелесну оплодюу. ( www.kolubarske.rs)// Наши војници донирали пакете с храном дјечјем дому у Кенији. (https://www.24sata.hr)// Активисти омладинске организације ВИФО донирали „Колевки” играчке, одећу, обућу и књиге... (https://www.subotica. com)//...четири војвођанска предузећа ће установама или локалним самоуправама у покрајини донирати робу вредну укупно око 150.000 евра... (http://rtv.rs)

Иако се по својим структурним и морфосинтаксичким обележјима, као и по могућности да се реализују у два различита синтаксичка обрасца, реченице са глаголом „донирати” у великој мери уклапају у постојећи систем реченица бенефактивног значења са глаголима типа „даровати”, оне поседују и два специфична обележја која указују да конструкције са овим глаголом још увек нису у потпуности асимиловане у остатак језичког система. Прво од тих обележја односи се на значењске карактеристике бенефактора и бенефицијента - у свим случајевима (када је о бенефицијенту реч) и са једним изузетком (када је о бенефактору реч) именичке фразе којима су приписане ове семантичке улоге означавају групу људи, организацију или колектив. Друга специфичност конструкција са глаголом ,донирати” односи се на могућност пасивизације ових реченица. Док се за све друге глаголе анализиране у овом раду могу конструисати кореспондентне пасивне конструкције за оба структурна типа реализације VP (уп. Марко је даровао/нудио/послужио Ану архивским вином : Ана је дарована/нуђена/послужена архивским вином и Марко је Ани даровао/нудио/послужио архивско вино : Архивско вино је даровано/нуђено/ послужено Ани), то није случај са реченицама конституисаним са глаголом „донирати”. Пасивне реченице са овим глаголом могу се конструисати само када је он реализован у конфигурацији $\mathrm{V}+\mathrm{NP}_{1 d a t}+\mathrm{NP}_{2 a c c}$ док пасивизацијом алтернативне конструкције настаје неграматична реченица (уп. Власник фармацеутске компаније донирао је болници вредну медицинску опрему : Болници је донирана вредна медицинска опрема са Власник фармацеутске компаније донирао је болнииу вредном медицинском опремом : "Болница је донирана вредном медицинском опремом). ${ }^{7}$

\footnotetext{
${ }^{7}$ Колико је делатна и моћна тежња језичког система да све што одступа од већ успостављених схема и образаца „нормализује” и уклопи у већ постојеће типове структура, добро илуструје следеће искуство: када сам пре непуних шест месеци у потрази за грађом за овај рад вршила претрагу World Wide Web-a, нисам нашла ниједан пример реченице са глаголом ,донирати" у облику партиципског пасива и допуном у инструменталу. Када сам данас извршила ту исту претрагу наишла сам на следећи пример: Модератор поздравља присутне и захваљује на доласку на свечано отварање учиониие која је донирана опремом твртке Proaxis. (www.event-
} 


\section{3. ОПШТА ОБЕЛЕЖЈА БЕНЕФАКТИВНИХ КОНСТРУКЦИЈА СА ГЛАГОЛИМА ТИПА „ДАРОВАТИ”}

3.1. Уз примарно и одређујуће својство конструкција са бенефактивним значењем с глаголима типа „даровати” - да се могу реализовати у два алтернирајућа структурна обрасца $\left(\mathrm{V}+\mathrm{NP} 1_{\text {acc }}+\mathrm{NP} 2_{\text {ins }}\right.$ и $\left.\mathrm{V}+\mathrm{NP} 1_{\text {dat }}+\mathrm{NP} 2_{\text {acc }}\right)-$ могуће је издвојити и друге заједничке карактеристике овог типа конструкција: 1. глаголске допуне могу стајати у било ком поретку у односу на глагол, али је типичан, немаркиран редослед конституената $\mathrm{V}+\mathrm{NP} 1_{\text {dat }}+\mathrm{NP} 2_{\text {acc }}$ у конструкцији са дативом и $\mathrm{V}+\mathrm{NP} 1_{\text {acc }}+\mathrm{NP} 2_{\text {ins }}$ у конструкцији са инструменталом. 2. У конструкцији $\mathrm{V}+\mathrm{NP} 1_{\text {dat }}+\mathrm{NP} 2_{\text {acc }}$ носилац семантичке улоге бенефицијент је $\mathrm{NP}_{\mathrm{dat}}$, док је носилац семанричке улоге тема $\mathrm{NP}_{\text {acc. }}$ У конструкцији $\mathrm{V}+\mathrm{NP} 1_{\text {acc }}+\mathrm{NP} 2_{\text {ins }}$ ситуација је обрнута - носилац семантичке улоге бенефицијент је $\mathrm{NP}_{\text {acc }}$, а тема се изражава именичком синтагмом у инструменталу. 3 . Ни у једном структурном типу конструкције није облигаторна реализација обе допуне - у зависности од комуникативне ситуације и ширег језичког контекста могуће је испуштање бенефицијента: Даровао је ... у добротворне сврхе тридесет хиљада...// Преко юега [сте] нудили нагодбу.// Почеше служсити чајем са прженим ... крухом.// Архимандрит, призивајући у себи све сотоне на главе ових безазорних ... нуди ... Ђаконијама, или теме: Паде му на памет да су његови пређи од памтивијека помагали и даривали ту исту иркву.// ... рекао је Д. након што је даровао новорођенчад.// Обје базилике ьезин син Константин богато надари и даде их раскошно уресити.// Осман-бег ... пије и нуди свима, највише новој хануми ... 4. И један и други тип конструкције могу се пасивизовати тако што $\mathrm{NP}_{\text {aсc }}$ из активне конструкције (било да је носилац улоге бенефицијент или улоге тема) постаје субјекат ( $\left.\mathrm{NP}_{\text {nom }}\right)$ кореспондентне конструкције с партиципским пасивом (уз ограничење које се односи на глагол „донирати”). Пошто се језици разликују у односу на то која се од две допуне дитранзитивних глагола у активној конструкцији може реализовати као субјекат пасивне конструкције (Кинан и Драјер 2007: 348), могућност да и бенефицијент и тема буду субјекти реченица с партиципским пасивом представља типолошки релевантно дистинктивно својство овог типа синтаксичких конструкција у српском језику.

3.2. Када је о односима класе глагола типа „даровати” према другим сродним класама глагола реч, уочљиво је да се они налазе на својеврсном пресеку између две глаголске класе са којима деле нека синтаксичка и семантичка обележја и са којима формирају својеврсни лексичко-валентни континуум. На једном крају тог континуума били би дитранзитивни глаголи типа „частити” који се реализују искључиво у оквиру обрасца $\mathrm{V}+\mathrm{NP} 1_{\text {acc }}+\mathrm{NP} 2_{\text {ins }}$, при чему је

planner.com.hr) Претпостављам да ће се наредних месеци/година видети да ли је реч о хапаксу, или ће се глагол „донирати” у свему, па и у могућностима за пасивизацију, изједначити са осталим глаголима из групе „даровати”. 
$\mathrm{NP}_{\text {acc }}$ носилац семантичке улоге бенефицијент, a $\mathrm{NP}_{\text {ins }}$ носилац семантичке улоге тема. Међу глаголе овог типа убрајају се: обдарити, гостити, погостити, дворити, наградити, частити, почастити, поткупити, хранити, нахранити, накљукати, опити, напити, снабдети и сл. На другом крају континуума били би глаголи који се реализују искључиво по обрасцу $\mathrm{NP} 1_{\text {dat }}+\mathrm{NP} 2_{\text {acc }}$, при чему је $\mathrm{NP}_{\text {dat }}$ носилац улоге бенефицијент, а $\mathrm{NP}_{\text {acc }}$ носилац улоге тема. У ову глаголску групу сврставају се глаголи поклонити, купити, предати, пружити, дати, додати, уручити, наручити, набавити, послати, рећи, причати, показати, представити, предавати, читати, писати и бројни други. Глаголи типа „даровати" налазе се у пољу пресека између ове две групе (в. Дијаграм 1.).

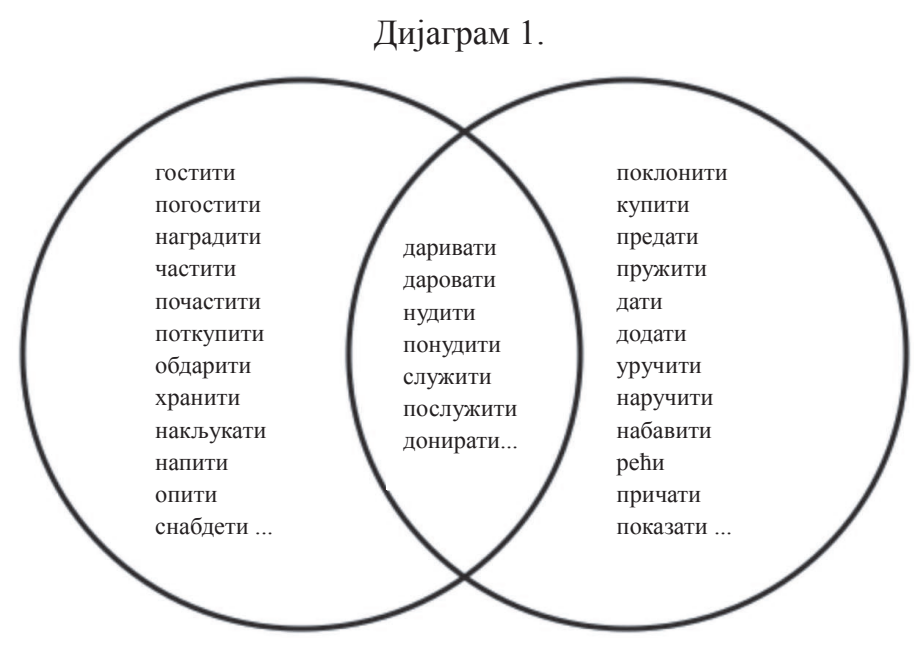

Постојање оваквог лексичко-валентног континуума није обележје само глаголске класе „даровати” и сродних класа које су у њега укључене - континууме сличног типа формирају и друге класе глагола. Један такав континуум формирају и глаголи уз које је могућа тзв. локативна алтернација са значењски и валентно сродним глаголима уз које тај тип пермутације аргумената није могућ. Исто важи и за све друге глаголске поткатегорије уз које је могућ било који облик инверзије/ротације допуна. ${ }^{8}$

Иако је уочавање и утврђивање поља простирања (обима), као и прецизан опис појава које карактеришу поједине лексичко-валентне континууме у српском и другим језицима само по себи питање од значаја за адекватан граматички опис једног језика, оно има и шире теоријске импликације. На-

${ }^{8}$ У Московљевић Поповић ibid.: 70-76 идентификовано је девет оваквих класа глагола уз које је могућа пермутација/ротација допуна и једна глаголска класа уз коју је могућа алтернација $\mathrm{NP}_{\text {loc }} \leftrightarrow$ субјекат, уз напомену да их вероватно има и више. 
име, формулисање одговарајућих правила повезивања нивоа семантичке, аргументске структуре предиката са нивоом синтаксичке реализације његових аргумената (које представља још увек недостигнут циљ коме тежи највећи број истраживања у савременој синтаксичкој и семантичкој теорији) тешко да ће бити могуће без претходног успостављања и дефинисања значењских и валентних поља која обухватају поједини лексичко-валентни континууми у различитим језицима, укључујући и српски.

\section{ИЗВОРИ}

МC - Речник српскохрватскога књижевног језика, књ. 1-3, Нови Сад-Загреб: Матица српска-Матица хрватска, књ. 4-6, Нови Сад: Матица српска, 1967.

AJ - Андрија Јовићевић. Ријечка нахија у Црној Гори, Српски етнографски зборник, књ. XV.

ДБ_ЂМ - Душан Баранин. Баво у манастиру. Београд: Вук Караџић, 1966.

ДЂ_СВ - Душан Ђорђевић. Сточни вагон. Врање: Врањске књиге, 2008.

ПС - Павле Соларић. Гозба. Сабране пјесме. Београд: АМИ, 1999.

\section{ЕлЕКтРонски извоРи:}

www.rastko.rs, www.politika.rs, www.event-planner.com.hr, www.blic.rs, www.ntv.ba, www.old.fil.bg.ac.rs, www.forum.hr, priceizbosne.blogspot.com, os-kustosija-zg.skole.hr, https://books.google.rs, www.zeljeznice.net, www.most. ba,www.jutarnji.hr, www.spiritofbosnia.org, http://www.bibliovcica.com, https:// archive.org, www.b92.net, www.matica.hr, www.bildungsserver.com, www.zgnadbiskupija.hr, www.haoss.org, www.instagram.com, www.fokuzz.com, www. bezpitanja.rs, www.roditeljportal.com, www.index.hr, www.vreme.com, www. kriticnamasa.com, www.rts.rs, www.titles.box.sk, www.dominomagazin.com, https://vukajlija.com, www.sokovi.net, www.poreklo.rs, www.novosti.rs, http:// rtv.rs, alas.matf.bg.ac.rs, www.manastir-lepavina.org, https://eteia.home.xs4all. nl, www.novine.ca, www.roditeljportal.com, www.ukat.org.rs, www.ringeraja. rs, www.mojekrpice.rs, www.danas.rs, www.voanerges.rs, www.hercegovina. info, https://sr.wikisource.org, www.pravda.rs, www.rtvpancevo.rs, www.tvl.rs, www.archive-hr-2013.com, www.hrvatskarijec.rs, www.infomarket.co.rs, www. gloria.rs, glossy.espreso.rs, https://www.vice.com, www.tripologia.com, www. putovanja.info, www.nezavisne.com, engleskifudbal.com, https://sr-rs.facebook. com, www.knjizevnicasopis.com, glaszapadnesrbije.rs, www.express.hr, www. 
teen385.com, https://issuu.com, www.sidskiportal.net, www.slobodnadalmacija. hr, www.mondo.rs, www.24sata.hr, www.rzsport.gov.rs, https://trend.com.hr, www. skyscrapercity.com, www.os-ntesla-ri.skole.hr, https://issuu.com/rotary_magazin, www.kolubarske.rs, www.subotica.com.

\section{ЛИТЕРАТУРА}

Блејк 1994: Barry Blake, Case, Cambridge: CUP.

Зовко Динковић 2007: Irena Zovko Dinković, „Dative Alternation in Croatian”, Suvremena lingvistika, 63, 65-83.

Ивић 1954/2005: Милка Ивић, Значена српскохрватског инструментала и юихов развој (синтаксичко-семантичка студија), Београд: САНУ-Београдска књига-Институт за српски језик САНУ.

Кинан и Драјер 2007: Edward L. Keenan и Matthew S. Dryer, „Passive in the world's languages", y: Timothy Shopen (ed.), Language Typology and Syntactic Description Vol. 1: Clause Structure, New York: Cambridge University Press, 325-361.

Китила и Зуњига 2010: Seppo Kittilä и Fernando Zúñiga, „Introduction. Benefaction and malefaction from a cross-linguistic perspective", y: Fernando Zúñiga и Seppo Kittilä (eds.), Benefactives and malefactives : typological perspectives and case studies, Amsterdam, Philadelphia: John Benjamins, 1-28.

Ковачевић 1992: Miloš Kovačević, Kroz sintagme i rečenice, Sarajevo: Svjetlost.

Ковачевић 2017: Милош Ковачевић, „Интердепенденција пермутабилних форми правог и неправог објекта у синтагмама с глаголом нуди$m u$ ", излагање на 47. Међународном научном састанку слависта у Вукове дане, 14-18. IX 2017. Београд.

Кристал 1985: Dejvid Kristal, Enciklopedijski rečnik moderne lingvistike, Beograd: Nolit.

Левин 2013: Beth Levin, „Verb classes within and across languages”. <https://web. stanford.edu/ bclevin/vclass13.pdf>. 23. 8. 2015.

Леман et al. 2000: Christian Lehmann, Yong-Min Shin, Elisabeth Verhoeven, Direkte und indirekte partizipation. Zur Typologie der sprachlichen Repräsentation konzeptueller Relationen. Munich: Lincom Europa.

Маљчуков et al. (ур.) 2010: Andrej Malchukov, Martin Haspelmath, Bernard Comrie, (eds.), Studies in ditransitive constructions : a comparative handbook, Berlin/New York: Walter de Gruyter. 
Московљевић 2000: Jasmina Moskovljević, Supkategorizacija glagola u savremenoj lingvističkoj teoriji. Doktorska disertacija. Filološki fakultet, Beograd.

Московљевић Поповић 2007: Jasmina Moskovljević Popović, Ogledi o glagolskoj potkategorizaciji, Beograd: Čigoja.

Ружић 2005: Владислава Ружић, „Проста реченица као синтаксичка целина”, у: Предраг Пипер, Ивана Антонић, Владислава Ружић, Срето Танасић, Људмила Поповић, Бранко Тошовић. Синтакса савременог српског језика. Проста реченица. У ред. Милке Ивић. Београд: Институт за српски језик САНУ, Београдска књига. Нови Сад: Матица српска.

Стевановић 1979: Михаило Стевановић, Савремени српскохрватски језик II - Синтакса, Београд: Научна књига.

\section{ON BENEFACTIVE CONSTRUCTIONS WITH VERBS OF THE TYPE 'DAROVATI'}

\section{Summary}

The purpose of this paper is twofold: 1 . to analyze benefactive constructions with ditransitive verbs of the type 'darovati' ('to give as a gift') in contemporary Serbian language and to describe their specific lexico-grammatical features; 2 . to discuss the relationships of the verb class 'darovati' with other verb classes with similar semantic and valency features, but with different syntactic properties. The group of 'darovati' verbs in Serbian is not a large one - it comprises only fifteen verbs, but it shows some interesting structural properties. Namely, these verbs allow more than one way of expressing their arguments, i. e. they participate in the dative alternation - one of the few syntactic alternations involving arguments within the VP. Constructions with the verbs of this type are characterized by an alternation between $\mathrm{V}+$ $\mathrm{NP}_{\text {lacc }}+\mathrm{NP}_{\text {2ins }}$ frame and $\mathrm{V}+\mathrm{NP}_{1 \text { dat }}+\mathrm{NP}_{\text {2acc }}$ frame. The $\mathrm{NP}_{\text {ins }}$ that is the oblique object (and the Theme) in the first frame, turns up as the $\mathrm{NP}_{a c c}$ that is the direct object (and the Theme) in the second frame. In a similar way, $\mathrm{NP}_{a c c}$ that is the direct object (and the Beneficiary) in the first frame, turns up as the $\mathrm{NP}_{\text {dat }}$ that is the indirect object (and the Beneficiary) in the second frame. The first two sections of the paper focuse largely on presenting the relevant data and on analysing the intricacies of these alternating constructions. In the third section, the concept of lexical and valency continuum is introduced and discussed.

Keywords: verb class 'darovati'('to give as a gift'), syntactic alternations; benefactor, beneficiary; lexical and valency continuum; contemporary Serbian language

Jasmina D. Moskovljević Popović 